\title{
Attributing decadal climate variability in coastal sea-level trends
}

\author{
Sam Royston $^{1}$, Rory J. Bingham ${ }^{1}$, and Jonathan L. Bamber ${ }^{1,2}$ \\ ${ }^{1}$ School of Geographical Sciences, University of Bristol, UK \\ ${ }^{2}$ AI4EO, Technical University Munich, Germany
}

Correspondence: Sam Royston (s.royston@bristol.ac.uk)

\begin{abstract}
Decadal sea-level variability masks longer-term changes due to natural and anthropogenic drivers in short duration records and increases uncertainty in trend and acceleration estimates. When making regional coastal management and adaptation decisions, it is important to understand the drivers of these changes to account for periods of reduced or enhanced sea-level change. The variance in decadal sea-level trends about the global-mean is quantified and mapped around the global coastlines of the Atlantic, Pacific and Indian Oceans, from historical CMIP6 runs and a high-resolution ocean model forced by reanalysis data. We reconstruct coastal, sea-level trends via linear relationships with climate mode and oceanographic indices. Using this approach, more than one-third of the variability in decadal sea-level trends can be explained by climate indices at $24.6 \%$ to $73.1 \%$ of grid cells located within $25 \mathrm{~km}$ of a coast in the Atlantic, Pacific and Indian Oceans. At $10.9 \%$ of the world's coastline, climate variability explains over two-thirds of the decadal sea-level trend. By investigating the steric, manometric and gravitational components of sea-level trend independently, it is apparent that much of the coastal ocean variability is dominated by the manometric signal, the consequence of the open-ocean steric signal propagating on to the continental shelf. Additionally, decadal variability in the GRD signal should not be ignored in the total. There are locations such as the Persian Gulf and African west coast where decadal sea level variability is historically small, that are susceptible to future changes in hydrology and/or ice mass changes that drive intensified regional GRD sea-level change above the global-mean. The magnitude of variance explainable by climate modes quantified in this study infers an enhanced uncertainty on projections of short- to mid-term regional sea-level trend.
\end{abstract}

\section{Introduction}

Sea level variability at the coast is driven by a variety of global- to local-scale factors. Understanding the drivers of variability due to decadal-scale, intrinsic climate variability in historical and contemporary observations improves our understanding of sea-level change and enhances our ability to predict future, near-term sea-level change. By subtracting climate-driven sea level from observations, a more consistent global mean sea level can be obtained from altimetry (Nerem et al., 2018) and tide gauge data (Frederikse et al., 2018). One aim is to elucidate anthropogenically-driven sea level change from climate variability (Hamlington et al., 2014, 2019). When climate variability can be explained, by reducing both the magnitude and auto-regressive nature of variability in the signal, linear-trend and acceleration standard errors can be reduced. This has been successfully applied globally (e.g. Hamlington et al., 2013; Nerem et al., 2018; Hamlington et al., 2020c) and regionally, from climate variability dominated by atmosphere-ocean interactions (e.g. Zhang and Church, 2012; Richter et al., 2020; 
https://doi.org/10.5194/os-2022-3

Preprint. Discussion started: 7 February 2022

Hamlington et al., 2020b; Wang et al., 2021) and intrinsic variability in eddy-rich regions (Sérazin et al., 2016). Climate model runs using historical forcing exhibit redistribution of the spatial patterns in sea-level rise associated with climate variability and intensification of sea-level rise in some areas that may be a result of anthropogenic forcing (Fasullo and Nerem, 2018). Understanding the driving mechanisms behind local, decadal sea level could lead to improved short- to medium-term forecasts of coastal sea-level change.

Regional sea level is projected to vary by $30 \%$ from the global mean, according to climate model evaluations (IPCC, 2019). A proportion of regional variation in sea level rise comes from patterns due to anthropogenically induced forcings, in particular changes to ocean heat content and surface winds drive changes in ocean circulation, the location of fronts, and mixed layer / thermocline depth, which induce a sea level change (Fasullo and Nerem, 2018; Fasullo et al., 2020; Peyser et al., 2016; Richter et al., 2020, e.g.) and variations to the gravitational, rotational and deformational (GRD) equipotential determining the sea surface, due to mass redistribution such as ice sheet mass loss. The remainder of the regional variation we describe hereafter as atmospheric and/or oceanic 'internal' variability. Local sea-level trends greater than $10 \mathrm{~mm} \mathrm{y}^{-1}$ on 10 -year timescales and over $1 \mathrm{~mm} \mathrm{y}^{-1}$ on 30-year timescales are observed in areas of the Pacific Ocean driven by climate variability; climate variability may potentially contribute centimetres of sea-level change over any given 10 year period, which local planners and stakeholders need to account for (Hamlington et al., 2020a). This internal variability may affect the magnitude of regional sea level trends calculated over durations up to 50 years (Carson et al., 2015, 2019). Internal sea-level variability related (linearly) to climate indices shows larger correlation coefficients at coastal locations in tide gauge data than in open ocean altimetry (Wang et al., 2021).

Decadal variability in global-mean sea level is dominated by the El Niño Southern Oscillation (ENSO) and Pacific Decadal Oscillation (PDO) and their evolution in time (Hamlington et al., 2013; Nerem et al., 2018; Hamlington et al., 2020c). Because these signals are large and affect a large proportion of the global-ocean area (being equatorial / tropical), they dominate the global signal. But other climate processes, described by other major indices, of course also affect local sea-level variability (Woodworth et al., 2019).

The Pacific Ocean decadal sea-level variability is dominated by the ENSO and PDO processes (e.g. Zhang and Church, 2012; Hamlington et al., 2019). Additionally, the Southern Annular Mode (SAM) and Indian Ocean Dipole (IOD) can also be related to sea-level variability in the Pacific Ocean (e.g. Frankcombe et al., 2015), with the IOD dominating sea-level variability in the Indian Ocean (Nidheesh et al., 2019). In the North Atlantic Ocean and North Sea, variability can be related to the North Atlantic Oscillation (NAO) and East-Atlantic Pattern (e.g. Frederikse et al., 2018; Kleinherenbrink et al., 2016). We extend these analyses by focusing only on coastal sea level and we remove the global-mean sea level at each time step to investigate regional, spatial differences.

Although the spatial variability of regional, decadal-scale sea level trends are dominated by the steric component (Richter et al., 2020), manometric sea level changes dominate intrinsic variability at the coast (Penduff et al., 2019; Llovel et al., 2018). When a steric-driven disturbance in the open-ocean sea surface height nears a coast, the density-driven change over a shallowing water column cannot fully match that in the open ocean and a pressure gradient develops in the sea surface. The geostrophic balance is maintained by redistribution of mass onto the shelf, such that sea-level change at the coast exhibits a 
https://doi.org/10.5194/os-2022-3

Preprint. Discussion started: 7 February 2022

predominantly manometric signal (Landerer et al., 2007; Yin et al., 2010; Bingham and Hughes, 2012; Penduff et al., 2019). We therefore also investigate the components of sea level variability at the coast.

Here we use a 53-year run of a high resolution ocean model to quantify and characterise decadal-scale sea level trend variability at the local, coastal scale (with the global-mean removed). A comparison is made with the CMIP6 historical run ensemble mean and spread. Climate model runs will not, in general, mimic the timing of internal atmosphere-ocean variability correctly but should capture much of its magnitude in the ensemble spread. Observed regional variability can be greater than coarse models suggest (Meyssignac et al., 2017; Carson et al., 2019), hence we compare the high-resolution run with the CMIP6 ensemble. These model runs are computationally expensive and we discuss the potential to use the relationship between sea level variability and climate indices. We exploit the correlation of climate mode indices with the leading principal components (PCs) of an empirical orthogonal function (EOF) decomposition to reconstruct decadal, coastal sea-level trend by a linear relationship. With our focus at the coast, the reconstruction is applied to satellite altimetry and tide gauge observations and the variability of coastal sea-level trends discussed.

\section{Method}

Although ENSO variability dominates the spatial pattern of sea-level variability on decadal timescales, we wish to investigate if particular climate processes dominate sea-level trends, at the coast, over different regions, and for each component of sea-level change.

Firstly, the magnitude of variance in regional sea level and its trend, as a deviation from the global mean at each time step, are determined from ocean models as a sum and in its component parts of manometric (model ocean bottom pressure) and steric contributions, plus the gravitation, rotation and solid-Earth deformation response (GRD) contribution deviation from the global-mean not included in climate models (refer to Gregory et al. (2019) for terminology).

We use output from a high-resolution (nominally $1 / 12^{\circ}$ ), eddy-resolving ocean model (NEMO) run over 58 years at monthly resolution from 1958-2015, in which the component steric and manometric signals sum to the sea level signal (Marzocchi et al., 2015; Moat et al., 2016). We use the later 53 years of data, allowing for 5 years' of spin-up. The global-mean sea level is removed at each time step, correcting for the Boussinesq approximation (Greatbatch 1992, Griffies and Greatbatch). The 'zos' variable for sea-level does not include atmospheric pressure effects and are therefore not included in this assessment. Thus the processed sea level quantifies the direction and variability of spatial patterns and intensification in sea level caused by real atmospheric forcing plus internal variability, excluding the inverse barometer effect. It is acknowledged that this variability will include influence from anthropogenic sources, because the high-resolution model is forced by reanalysis atmospheric data rather than natural forcing. The magnitude of variability is compared against the ensemble mean and spread of variance for the same time period from an ensemble of 43 historical forcing CMIP6 models.

The observed absolute sea level signal as observed by altimetry includes the GRD component that is spatially varying. The barystatic, global-ocean-mean volume change due to solid-Earth deformation is ignored in this study because we remove the 
https://doi.org/10.5194/os-2022-3

Preprint. Discussion started: 7 February 2022

(C) Author(s) 2022. CC BY 4.0 License.

global-mean at each time step. We add only the spatial geoid signal to the sea-surface height (SSH) from the models (with a global-ocean-mean of zero).

To quantify how much of the sea level variability can be described by a relationship with climate indices, where the impact of sea level change is highest - at the coast - we investigate reconstructing sea level from climate indices over a decadal timescale. We investigated both low-pass filtered and rolling linear trend in time for each coastal grid cell time-series and found the strongest relationship in the latter (not shown). We assume first-order auto-regressive (AR1) noise, appropriate for monthly sea level time series (e.g. Bos et al., 2013; Dangendorf et al., 2014; Haigh et al., 2014), by a generalised least-squares regression that solves for the annual- and semi-annual periodics as well as the trend. We apply an EOF analysis to the rolling decadal trends from the modelled component parts and compare against decadal trends in key climate indices.

To focus where the impact of sea level change is highest, and because the EOF analysis determines orthogonal bases from the first principal component (PC) with largest variability, we only apply the analysis to coastal regions. We define coastal by distance to the nearest coastline, selecting those model grid centres less than $25 \mathrm{~km}$ distance from one of the low resolution coastlines in the global self-consistent, hierarchical, high-resolution geography (GSHHG) database (following Penduff et al., 2019).

For the reconstruction, we use all leading EOFs that describe at least 5\% of the sea level trend variability for each component of sea-level change. The correlation of each principal component is determined with primary climate indices and, provided the correlation is significant (by $t$-test with the degrees of freedom reduced due to the auto-regressive nature of the signal; Emery and Thomson (2001)) a linear regression is performed for the leading PCs in turn with each climate index until all indices are associated with a PC or the correlation or PC are no longer significant.

Reconstructed trends are compared against the variability of running trends from the model, giving the variance explained by the climate index regression, calculated as the percentage ratio of trend variance at each grid cell, of the model-minusreconstructed residual over the model rolling trends. The variance explained by these reconstructions of course varies by the adequacy of a simple, linear model, and the number of leading principal component modes used in the reconstruction.

The reconstruction for the trend from 2008-2018 is compared against observed sea level from satellite altimetry to validate our technique. The reconstruction for running trends centred on 1968-2011 are compared against tide gauge observations at arbitrary locations, demonstrating locations where the variance explained appears to be good. The decadal trend variability from tide gauge observations and the reduction in variability explained by all significant PCs for manometric, GRD and steric sea level change combined and for each basin, using the reconstructed sea-level rolling trend at the nearest model grid cell to each tide gauge location. The tide gauge relative sea level are corrected for glacial isostatic adjustment (GIA) but we do not correct for contemporary GRD-induced vertical land movement (VLM) because of the limited number of tide gauges with co-located and benchmarked GNSS sites, instead removing the mean trend from tide gauge observed data. Rolling trends from observation data are treated identically to that from model data, a seasonal signal is solved for within the regression design matrix (an annual and a semi-annual periodic) and the noise is assumed to have an AR(1) characteristic. 
https://doi.org/10.5194/os-2022-3

Preprint. Discussion started: 7 February 2022

(c) Author(s) 2022. CC BY 4.0 License.

(c) (i)

\section{Data}

\subsection{High-resolution 58-year ocean model run: NEMO}

The total sea level signal is partitioned into steric and manometric sea level from the NEMO ORCA0083-N006 model run, details of which can be found in The NEMO Working Group (2019); Marzocchi et al. (2015); Moat et al. (2016). The model is applied to a high resolution ORCA tri-pole grid (nominally $1 / 12^{\circ}$ ) so is eddy-resolving, and is forced by the Drakkar Surface Forcing dataset version 5.2 (Dussin et al., 2016), from 1958 to 2015 inclusive. The forcing includes reanalysed atmospheric data, noting that a change in the data occurs in 1979, and freshwater fluxes (precipitation and snow). Freshwater runoff is added as seasonal cycles, and does not exhibit interannual changes.

Steric sea level is calculated using the TEOS-10 equation of state (TEOS-10, 2008) applied to temperature and salinity modelled values at each model depth level. The total and steric sea level anomaly are inherently corrected for the Boussinesq approximation (Greatbatch, 1994; Griffies and Greatbatch, 2012) and global-ocean-mean atmospheric pressure because we remove the global-mean of each at each time step.

The manometric sea level component is taken to be equal to the ocean bottom pressure anomaly, converted from pressure to mm change in height.

The ocean model has been shown to match observed variability well (Marzocchi et al., 2015). We additionally check that the linear trend from last decade of the model run, 2007-2016, with GRD added matches the altimetry observation of absolute sea level trend (Supplementary Information). In this analysis, only coastal locations, within $25 \mathrm{~km}$ of the low resolution GSHHG coastline, are considered.

\subsection{CMIP6 climate model historical runs}

Model runs from the $6^{\text {th }}$ Climate Model Intercomparison Program (CMIP6; Eyring et al. (2016)) are used to quantify the magnitude of internal ocean variability, to compare with the NEMO high-resolution model.

Model run data was obtained via JASMIN (UK data and storage facility, https://jasmin.ac.uk/users/access/) and may also be obtained from the WCRP portal (ESGF, 2021). Historical forcing (esm-hist) has been run in CMIP6 from 1850 to 2014 inclusive. Here we take the ' $z o s$ ' variable sea surface height, at monthly time stamps from January 1958 until the end of the run in December 2014 (noting this is one year shorter than the high-resolution NEMO run). The zos variable is interpolated onto a regular lat-lon $1 / 4^{\circ}$ grid for each run and the global-ocean mean is removed from each time step of each model. Appendix A lists the 43 CMIP6 model setups analysed in this study. In this analysis, only coastal locations, within $25 \mathrm{~km}$ of the low resolution GSHHG coastline, are considered.

\subsection{Gravitation, rotation and solid Earth deformation changes}

The ocean models do not include any GRD changes. Observations by their nature include GRD effects. The absolute sea level observed by satellite altimetry does not observe the global-ocean mean solid-Earth deformation and global-mean glacial 
https://doi.org/10.5194/os-2022-3

Preprint. Discussion started: 7 February 2022

(c) Author(s) 2022. CC BY 4.0 License.

isostatic adjustment (GIA) effects are usually subtracted as a correction. Altimetry does observe regional redistribution of the geoid when the anomalies are taken from a mean sea surface. Relative sea level observed by tide gauges include solidEarth deformation. To compare model data with observations, we add variability from a sea level fingerprint method applied to comprehensive data sets of land and cryospheric mass loading. The data set has been used to estimate the GRD effect on globalmean and basin-mean sea level trends where the time-varying vertical land movement was used to correct tide gauge relative sea level records (Frederikse et al., 2020b, a). The GRD geoid fingerprints include the effect of mass changes in glaciers, the Greenland and Antarctic Ice Sheets, including uncharted glaciers and peripheral glaciers, and from natural terrestrial water storage (TWS), dam retention (or reservoir impoundment) and groundwater depletion. Here, we determine decadal rolling trends from the geoid variability of the sea level fingerprint since 1958 and ignore the barystatic (global-mean) component since we are interested in the spatial variability.

\subsection{Absolute sea level: Satellite altimetry}

Absolute sea level is defined from a multi-mission, gridded product on a $1 / 4^{\circ}$ grid with the most up-to-date corrections and processing available (ESA SLCCI v2; Legeais et al. (2018); ESA (2018)). We replace the global-mean GIA correction with a spatial correction, defined by the global-mean solid-Earth deformation response over the global-ocean $\left(-0.21 \mathrm{~mm} \mathrm{y}^{-1}\right.$ for the ICE6G-VM_D GIA model (Peltier et al., 2015; Peltier, 2018)) plus the gridded geoid variation. We additionally correct the gridded satellite altimetry for solid-Earth deformation associated with recent mass loading of the oceans, following Frederikse et al. (2020b) and using their published data (Frederikse et al., 2020a).

\subsection{Climate mode and oceanographic indices}

Major climate variability is represented by indices, derived from various atmospheric and oceanic observables, such as air pressure at sea level, sea surface temperature and surface wind speed or its gradient. Here, we determine the correlation of the principal component time series of rolling sea-level trends with the rolling trends of 6 major climate includes: the Pacific Decadal Oscillation (PDO; NOAA-NCEI (2020c)), El Nino Southern Oscillation (ENSO; Multivariate ENSO Index, NOAA-NCEI (2020a)), North Atlantic Oscillation (NAO; NOAA-NCEI (2020b)), Arctic Oscillation (AO; NOAA-CPC (2020)), Southern Annular Mode (SAM; Marshall (2020)) and Indian Ocean Dipole (IOD; GCOS (2020)).

Additionally, the effect of the Atlantic Meridional Overturning Circulation (AMOC) is investigated. The AMOC index is calculated here from the NEMO model runs, as an anomaly at each time step. The index is computed as the principle component of the low-pass filtered (1-year running mean) and zonally-integrated meridional transport, in Sv, and then the rolling trend is calculated from this index.

It is acknowledged that these indices are not independent of each other. However the EOF patternd and principal components of coastal sea-level change are orthogonal. Therefore only one climate index is associated with each PC and not repeated in the reconstruction. 
https://doi.org/10.5194/os-2022-3

Preprint. Discussion started: 7 February 2022

\subsection{Tide gauge observations}

Tide gauge observations are obtained from the Permanent Service for Mean Sea Level (Holgate et al., 2013) for revised local reference (RLR) stations only. The relative sea level is corrected for GIA (Peltier et al., 2015; Peltier, 2018) only, and no account is made for contemporary GRD-induced or other VLM, which may be non-linear. Monthly mean time series, omitting flagged data, are used to determine rolling trends and periods where less than $50 \%$ of data are missing in each rolling decade are omitted.

\section{Results and Discussion}

\subsection{Variance of decadal sea-level trend}

Over the 58-year NEMO model run, coastal sea-level rolling trends vary in time by a mean standard deviation of $3.6 \mathrm{~mm} \mathrm{y}^{-1}$, with some locations displaying a standard deviation in trends over $7.5 \mathrm{~mm} \mathrm{y}^{-1}$ (Fig. 1), which is significantly larger then the mean trend over the modelled period of $2.2 \mathrm{~mm} \mathrm{y}^{-1}$.

The variance of total SSH in the NEMO model run generally sits within the spread of variance in the CMIP6 ensemble. There is increased variance in the CMIP6 ensemble mean compared with the NEMO model run in the Northern Hemisphere, particularly in the Beaufort Straights, Hudson Bay, and the North Sea into the Baltic Sea, and to a lesser extent in the Mediterranean and Black Seas (comparing Fig. 1a and 1b). This effect in climate models is typical in semi-enclosed seas. In contract the NEMO model run displays a larger variance in sea level trends around the coast of Greenland, in the tropical West Pacific and west coast of Australia, in the Caribbean Sea and around Chesapeake Bay. However most of these differences lie within the CMIP6 ensemble spread and are therefore not significant.

This analysis confirms there is high variability in decadal sea-level trend in the Western Tropical Pacific Ocean. On the eastern side where the coast faces the open ocean, the signal is dominated by steric changes, but through the Indonesian Throughflow and in the marginal seas, the signal becomes manometric in nature (Fig. 2a,b). For most of the coastal locations, the variance in sea-level trend is dominated by manometric sea level change; in $48.2 \%$ of coastal locations defined from the NEMO grid the manometric sea level change shows the largest contribution to variance, in $32.3 \%$ of locations steric sea level is dominant and in $17.5 \%$ of locations the GRD effect is dominant.

Around the Greenland coast, in the vicinity of major ice mass loss that is variable in time, there is a large variability in decadal trends due to the GRD effect (Fig. 2c). The GRD signal driven by glacier and ice sheet mass loss also contributes more than one-quarter to the variability around south Alaska, Hudson Bay and the Canadian Arctic and Iceland, and to a lesser extent around the Patagonian ice sheet. It is noted that this analysis relates to absolute sea level equivalent, and VLM contributing to relative sea level is not considered. There is also a notable contribution from GRD in areas around the major river basins or other hydrology impacts (like groundwater abstraction or dam retention) where interannual variability in TWS is large, for example around the Amazon River basin, Niger River basin and the Persian Gulf. 
https://doi.org/10.5194/os-2022-3

Preprint. Discussion started: 7 February 2022

(C) Author(s) 2022. CC BY 4.0 License.

Even though in many of those regions the variability in decadal trend around the global-mean is small (around $1 \mathrm{~mm} \mathrm{y}^{-1}$ ), where the dominant contributions are GRD and/or local steric contributions from hydrology, future changes may exacerbate the trend. For example, in the Persian Gulf, decadal sea-level trends are dominantly affected by GRD changes over direct oceanographic changes in addition to global-mean sea-level rise. It is noted here there is a complex GRD signal from both hydrology and glacier mass loss. On the south-east African coast, as in much of the South Atlantic, where there are very few long-duration tide gauge measurements, the trend variability is small (less than $1 \mathrm{~mm} \mathrm{y}^{-1}$ ) in both the CMIP6 ensemble mean and NEMO model (Fig. 1a,b). Here, sea level variability is strongly influenced by GRD effects from the variability of hydrology, with the Amazon, Niger, Congo and Zambezi/Okavango basins driving more than $40 \%$ of sea-level trend variability in places (Fig. 2c). Long-term anthropogenic or climate change impacts on the hydrology in these locations are likely to intensify the regional trend about the global-mean.

\subsection{Climate index reconstruction of sea-level trends}

We reconstruct decadal running sea-level trends from climate index trends by ocean basin for steric and manometric sea level separately, and then combine the reconstructions. The reconstruction displays statistically significant correlations $(r>0.32$ for a two-sided $t$-test at $95 \% \mathrm{CI}$ with an auto-correlation of 0.5 in the rolling trends) along much of the global coastal locations (Fig. 3a). There is a notably poor correlation around South-East Africa, where the interaction of the Benguela and Agulhas currents and upwelling may interupt far-field climate-driven sea-level variability. The reconstruction explains much of the variance along the American continent's west coast and in the Tropical Pacific Ocean and Indonesian Throughflow to the West Australian coast and west coast of Asia (Fig. 3b). The primary mode explains more than half of the decadal trend variance in the semi-enclosed seas of East Mediterranean, Black and Baltic Seas. Along the traditionally under-sampled West African coastline between $10^{\circ} \mathrm{N}$ and the Mediterranean outflow at Gibraltar Straits and between 5 and $30^{\circ} \mathrm{S}$, the reconstruction explains between one-third and one-half of variability in decadal trends. The approach explains more than half of decadal trend variance over $25.8 \%$ of the global, non-polar coastal ocean, and with greater success in the Pacific Ocean where the ENSO variability is dominant (Table 1). Table 1 presents the proportion of grid cells located in each basin where the reconstruction explains more than one-third, one-half or two-thirds of the decadal sea-level trend variance (not areally averaged). The column 'SSH' refers to a reconstruction using only total SSH EOFs and the column 'DSL + steric' refers to a reconstruction summed from the EOFs of all sea-level components. For each major basin, the approach can explain more than one-third of the decadal trend variance for $24.6 \%$ to $73.1 \%$ of coastal locations (Table 1 ).

When considering the proportion of variance explained for a coastal location, the manometric sea level signal becomes important. High-resolution ocean models demonstrate altimetry-era sea level change is masked by oceanic intrinsic variability over 38\% of the global ocean (Llovel et al., 2018) and 17-20\% of coastal areas (Penduff et al., 2019). Penduff et al. (2019) show the variance in the steric part of the signal is reduced in coastal areas compared with the open ocean, the atmospherically forced steric signal emerges from intrinsic variability in coastal regions far less (5\% coastal area) than the manometric contribution (30\% coastal area). The shallowing water column in the coastal region requires a manometric response to the open-ocean steric signal (Bingham and Hughes, 2012; Dangendorf et al., 2021). This is the mechanism for the proportion of variance seen 
https://doi.org/10.5194/os-2022-3

Preprint. Discussion started: 7 February 2022

(c) Author(s) 2022. CC BY 4.0 License.
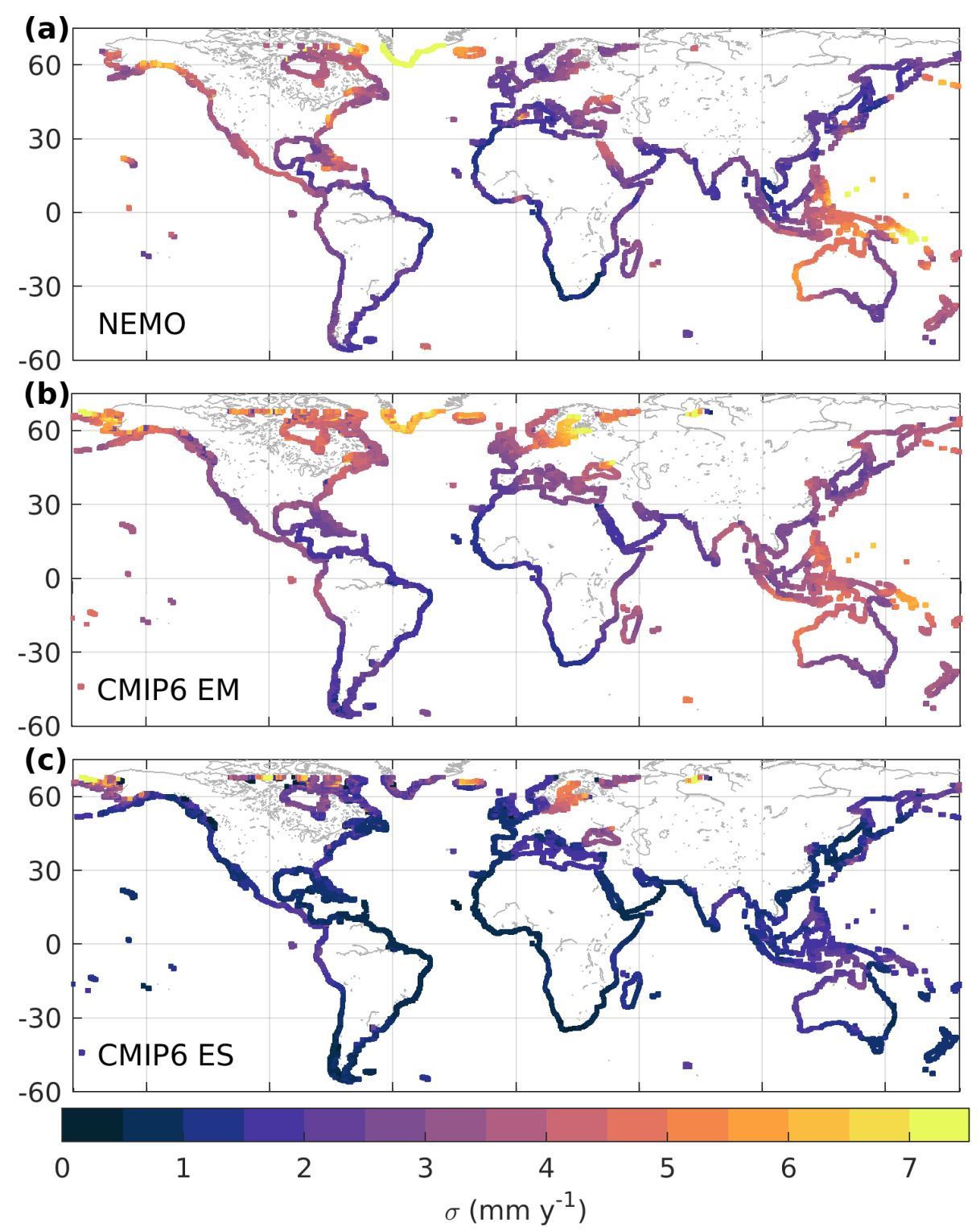

Figure 1. Standard deviation of decadal trends $\left(\mathrm{mm} \mathrm{y}^{-1}\right)$ in sea surface height from the NEMO model (a), the ensemble mean of the CMIP6 model runs (b) and the model spread (c). The SSH from the NEMO model and ensemble mean of CMIP6 model runs (a,b) include GRD.

in Fig. 2. Unfortunately satellite observations that measure mass changes through gravimetry, such as the GRACE mission, are unlikely to be able to resolve this signal close to land, because the variability in the equivalent water height on land is orders of magnitude greater than the ocean signal, leading to leakage and resolution issues. Thus, using the Argo data to verify steric sea level variability with climate change and using climate forecasts may provide short-term (as far ahead as the forecast for ENSO for example) indications of coastal sea level change. This has been recently demonstrated to work well 
https://doi.org/10.5194/os-2022-3

Preprint. Discussion started: 7 February 2022

(c) Author(s) 2022. CC BY 4.0 License.
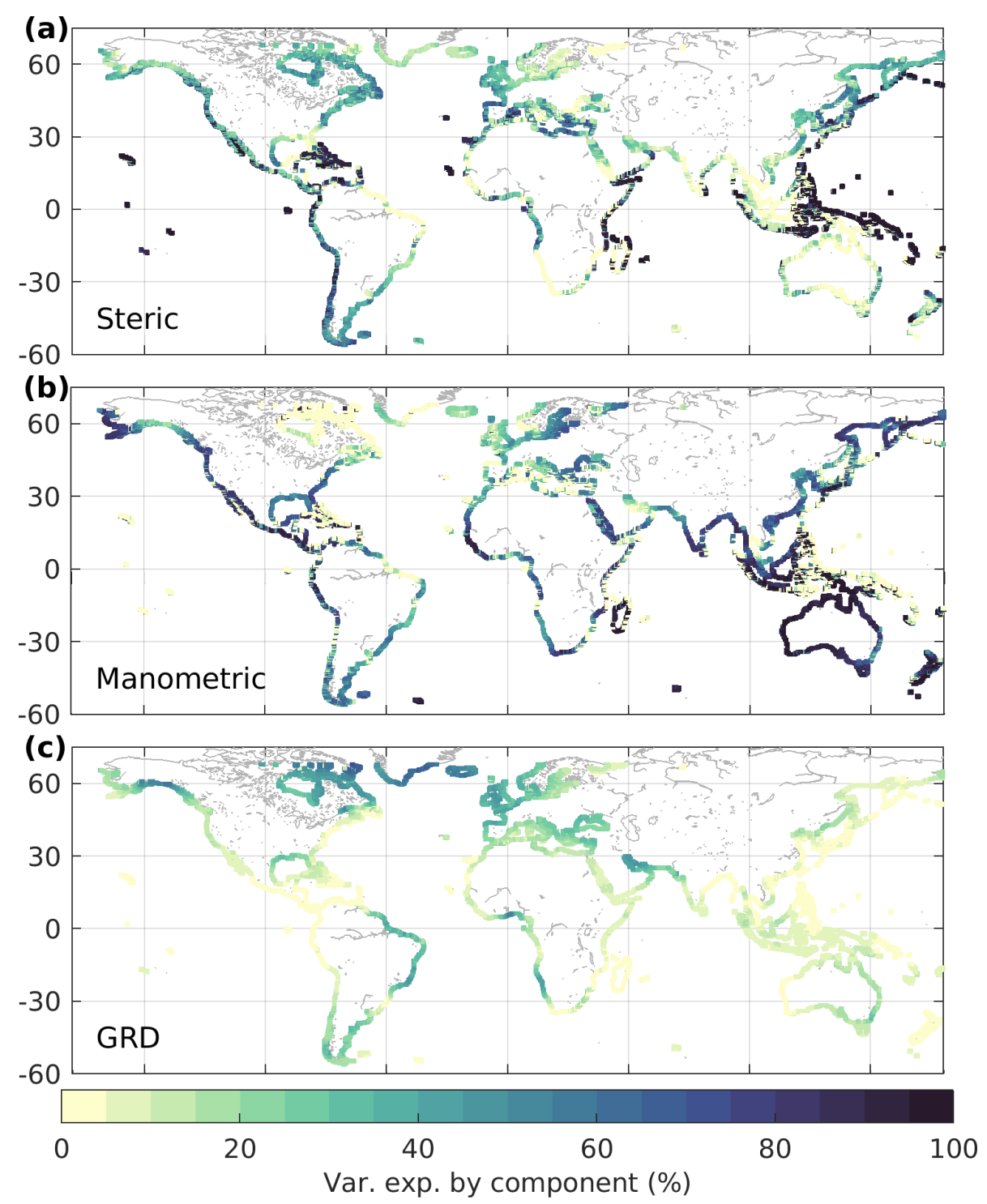

Figure 2. Proportion of variance explained (\%) of decadal trends in sea surface height from the NEMO model: by steric sea level (a), manometric sea level (b) and GRD respectively (c).

for some specific regions of the coast (Dangendorf et al., 2021). The first principal component modes from manometric and steric sea level are very similar to that from sea surface height and have highest correlation with the same climate indices (Supplementary Information). By adding the contribution from each component separately there is a marginal improvement in the overall variance explained by this approach (Table 1).

Oscillations in observed tide gauge decadal trends are explained well by the climate index reconstruction in some regions, in particular across the tropical Pacific and the coast of the Americas and on the Atlantic West coast (examples are given in Fig. 
https://doi.org/10.5194/os-2022-3

Preprint. Discussion started: 7 February 2022

(c) Author(s) 2022. CC BY 4.0 License.

(c) (i)
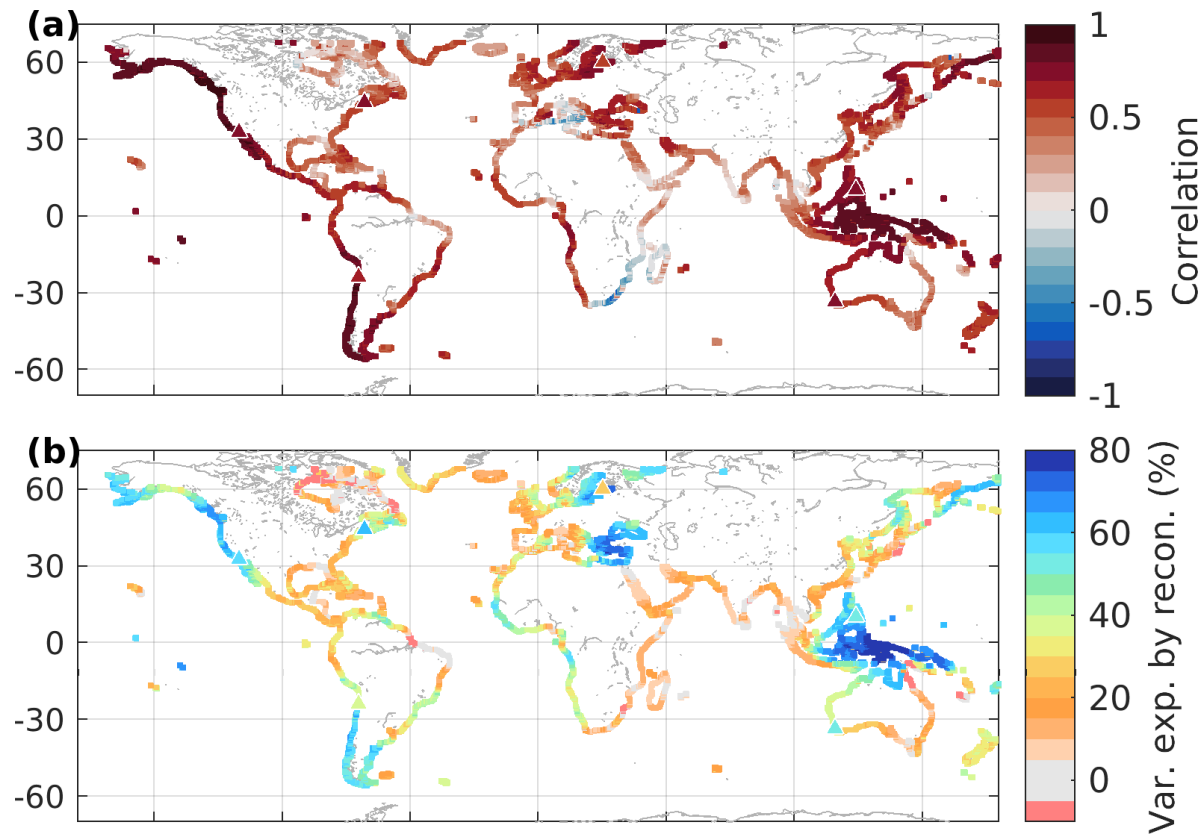

Figure 3. Comparison of decadal, rolling sea-level trends from the NEMO model plus GRD, and reconstruction using only climate indices: Pearson's correlation coefficient (a) and variance explained (b; \%). Results here sum reconstructed decadal trend from manometric sea level plus steric sea level by ocean basin. Triangles denote the locations of tide gauge observations shown in Fig. 4.

4). Along coastlines where it is expected a coastally-trapped boundary wave transmits sea level disturbances, it can be seen that the majority of the signal is manometric (Fig. 4c,e). Where the continental shelf is narrow, the reconstructed sea level is predominantly steric (Fig. 4b,d). In the tropical West Pacific, the dominant ENSO steric signal directly impacts tropical West Pacific tide gauge sites on the oceanward (eastern) coast, but the signal propagates through the Indonesian throughflow and around the island as a manometric signal, so that by Cebu the signal is predominantly manometric (Fig. 4a). The tide gauge data do not have contemporary VLM removed (except GIA), nor the nodal tide or inverse barometer correction made. For visualisation we simply remove the mean trend for the whole period considered.

For those locations with large magnitude variability (Fig. 1), much of that decadal signal can be attributed to climate forcing and reconstructed from climate indices. For $10 \%$ of the coastal locations in this study, over two-thirds of the regional decadal sea-level trend about the global-mean can be quantified by a linear relationship with climate index data (Table 1).

\subsection{Climate effect on recent coastal sea-level trends}

The reconstructed sea level variability due to primary climate modes can be compared against the spatially-comprehensive satellite altimetry data, with the global-mean trend removed (to emphasise regional patterns in sea-level change).

For a recent decade of observations, 2008-2018 inclusive, the reconstruction of sea level trends along the coast associated with climate indices (Fig. 5) captures the dipole of sea level trends across the Pacific Ocean and much of the decadal trend in 
https://doi.org/10.5194/os-2022-3

Preprint. Discussion started: 7 February 2022

(c) Author(s) 2022. CC BY 4.0 License.

(c) (i)

\begin{tabular}{lccc} 
Coastal Domain & > Var. Exp. & SSH & DSL + steric \\
\hline All basins & one-third & 48.2 & 44.5 \\
& one-half & 29.3 & 25.8 \\
& two-thirds & 7.2 & 12.3 \\
\hline \multirow{2}{*}{ Atlantic } & one-third & 41.2 & 28.7 \\
& one-half & 21.4 & 8.7 \\
& two-thirds & 4.8 & 0.0 \\
\hline \multirow{2}{*}{ Pacific } & one-third & 66.9 & 73.1 \\
& one-half & 46.6 & 54.2 \\
& two-thirds & 12.7 & 32.8 \\
\hline Indian & one-third & 19.6 & 24.6 \\
& one-half & 8.7 & 9.1 \\
& two-thirds & 0.3 & 0.0
\end{tabular}

Table 1. The proportion of coastal grid cells defined from the NEMO grid with more than one-third (33\%), one-half (50\%) and two-thirds (67\%) of decadal trend variance explained by the reconstruction. The values shown here are from assessment of the 'coastal domain' and the NEMO model runs. 'SSH' refers to the reconstruction using EOF and PC modes for the full SSH signal and 'DSL + steric' refers to the reconstruction by components, for manometric dynamic sea level, GRD and steric sea level associated with climate indices separately and then summed.

the Caribbean Sea, South Greenland and Black Sea, and the sign of the trend in south Greenland, the Baltic Sea and North West African coast. The reconstructed signal is not as strong as observed. The variance explained at coastal grid cell locations in the Atlantic and Indian Oceans is increased, although the variance is decreased by the reconstruction in the Pacific. The histogram of trends for this period are markedly more Gaussian when reconstructed with climate-index-related variability removed than the unaltered observations.

Notably in all basins, by removing the reconstructed variance by climate indices, the mean (median) coastal sea level trend for 2008-2018 is increased, by $0.7(0.2) \mathrm{mm} \mathrm{y}^{-1}$ globally (Table 2). It is noted that we expect climate variability has affected the global-mean sea level over the same period which we do not account for here, but we may conclude that coastal sea levels have been suppressed by the phase of climate variability in 2008-2018, compared with the entire-ocean mean.

\subsection{Sources of decadal variability and caveats}

Interannual sea level variability can develop purely as a response to non-linear interactions in oceanic intrinsic variability, and can evolve from seasonal forcing as strongly as from atmospheric forcing (Llovel et al., 2018). Oceanic intrinsic variability exceeds the forced response to atmospheric forcing at some lengthscales over several years in high resolution ensembles (Sérazin et al., 2015, 2016; Llovel et al., 2018; Penduff et al., 2019). Thus, sea level variability is the aggregated response, over integrating time-scales, of both atmospheric forcing and intrinsic variability in the system. It is acknowledged that the approach 
https://doi.org/10.5194/os-2022-3

Preprint. Discussion started: 7 February 2022

(c) Author(s) 2022. CC BY 4.0 License.

(c) (i)
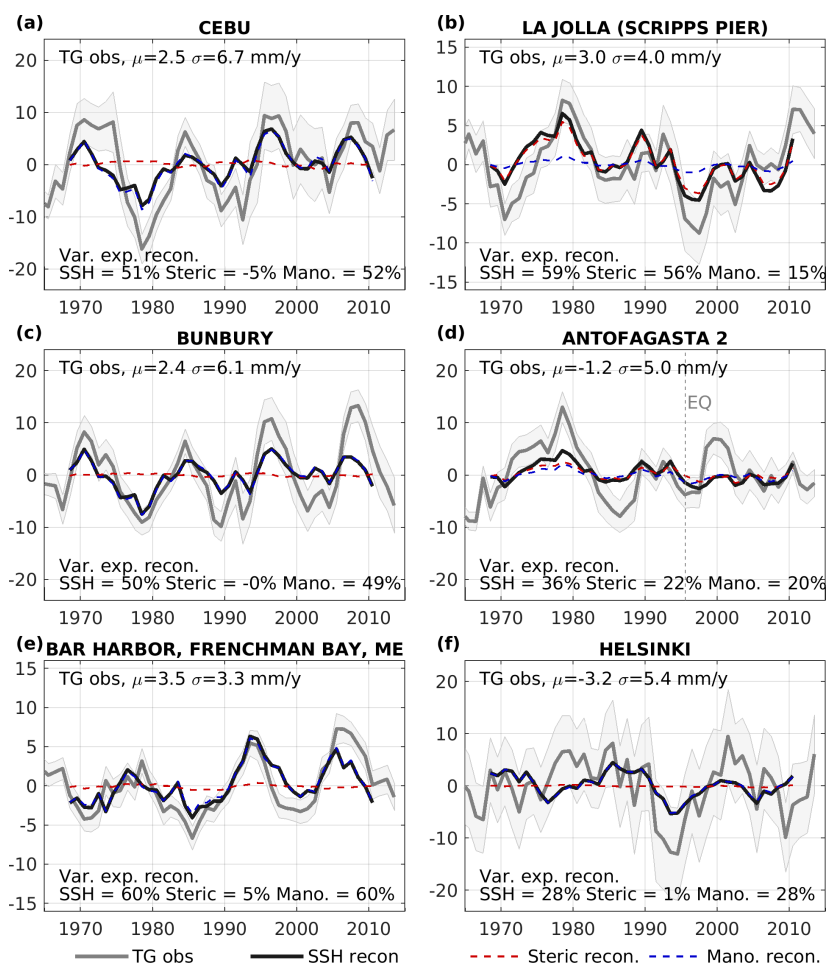

Figure 4. Observed sea level trends in tide gauge observed sea level ( $\mathrm{mm} \mathrm{y}^{-1}$; grey solid lines, triangles on Fig. 3), and the reconstructed decadal trends from all PCs for the appropriate basin, for steric sea level (red dashed), manometric plus GRD sea level (blue dashed) and the sum (black solid), together with a simple average coastal-global-mean (f). Note the time-mean sea level trend is removed from each tide gauge observed data for visualisation.

\begin{tabular}{llccc} 
Statistic & Coastal Domain & Obs. & Reduced & Diff. \\
\hline Std. dev. & Global & 4.2 & 3.3 & -1.0 \\
& Atlantic & 2.8 & 3.0 & 0.2 \\
& Pacific & 5.2 & 3.3 & -1.9 \\
& Indian & 4.6 & 3.7 & -1.0 \\
Mean & Global & 0.0 & 0.7 & 0.7 \\
& Atlantic & 0.8 & 1.1 & 0.3 \\
& Pacific & -0.1 & 0.6 & 0.7 \\
& Indian & -3.0 & -1.0 & 2.0
\end{tabular}

Table 2. Statistics of the global-coastal sea level trend from 2008-2018, observed by satellite altimetry and when reduced by the reconstructed sea level expected from climate index reconstruction for each basin $\left(\mathrm{mm} \mathrm{y}^{-1}\right)$.

could be improved by comparing the PCs with phase-lagged trends in the climate indices and/or with other metrics describing the forcing. 


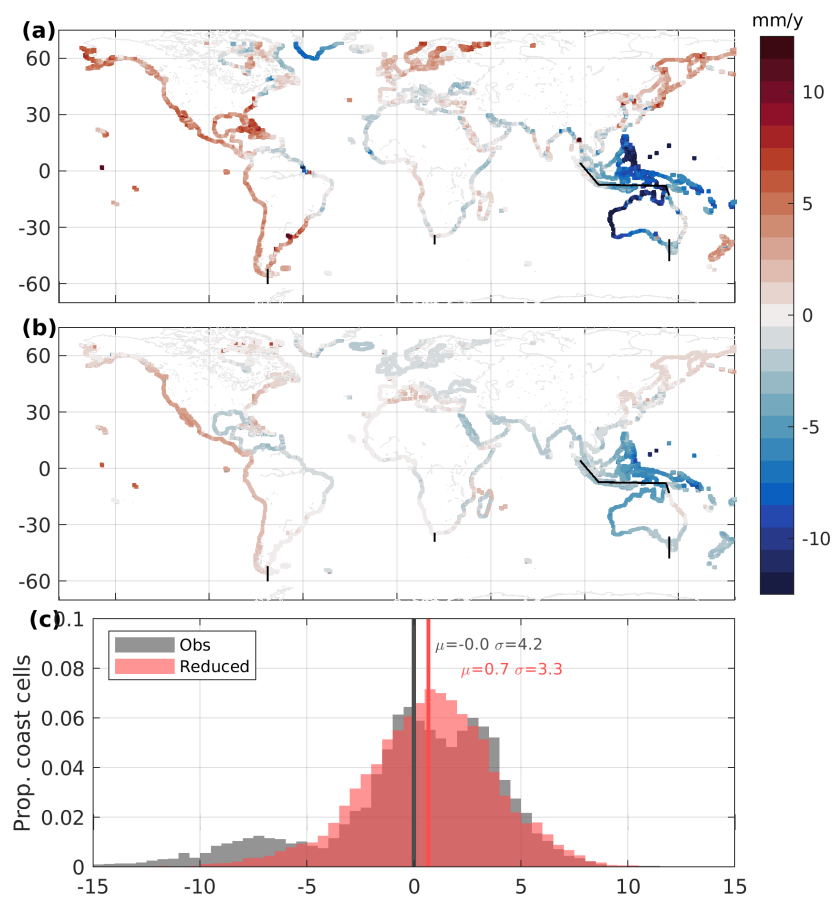

Figure 5. Comparison of 2008-2018 trend $\left(\mathrm{mm} \mathrm{y}^{-1}\right)$ from satellite altimetry and reconstruction. Observed decadal trend in satellite altimetry for the global mean removed (a) and the reconstructed decadal trend for each basin and component combined (b), with histogram (c) for all coastal grid cell locations for observations from satellite altimetry (grey) and the altimetry minus the reconstruction (so-called 'reduced' trends, red).

Globally, the ENSO and PDO have been shown to dominate the decadal-scale variability of coastal sea level over other climate processes (e.g. Hamlington et al., 2013; Nerem et al., 2018). Because the PDO or ENSO decadal variability dominate the power in sea level variability, the EOF bases on a global data set are forced to be orthogonal to that mode. To investigate other drivers, we further mask the data into three oceanic basins, the Atlantic, Pacific and Indian Oceans. By focusing on each oceanic basin in turn, the dominant mode(s) from each region can be identified (Supplementary Information).

Generally climate models display lower sea level variability than observed (Carson et al., 2015). In particular the CMIP5 models were found to simulate sea level variability comparable to observations but showed bias in trends (Meyssignac et al., 2017); other authors found that the long term memory, power-law character of sea level in CMIP5 models is too small, indicating the internal variability is too short-lived (Becker et al., 2016). Here, the use of a high resolution model goes some way to minimise that influence but we caution that the resulting reconstructed sea level variability and its trend should be thought of as a minimum rise or fall in sea level expected with climate index evolution.

It is acknowledged that the EOF patterns and their PCs developed here are somewhat model-dependant and because of the linear approach taken may incorporate anthropogenic as well as internal forcing patterns. 


\section{Conclusions}

The current temporal duration of high quality sea-level data with good spatial coverage conflates with the typical autocorrelated, integrated, long-memory time scale of variability in major atmosphere-ocean climate modes, recently shown for the open Pacific Ocean by Hamlington et al. (2020a). Therefore much of the current linear trend in steric and manometric components of sea level can be reconstructed from climate index data in some parts of the global-coast. This enables the possibility that observed sea level and its components can be reduced for climate variability, as has been applied for the total sea level signal at the global-scale (Nerem et al., 2018; Hamlington et al., 2020c) and spatial distribution in the Pacific Ocean (Hamlington et al., 2020b, a) and globally for time series (Wang et al., 2021).

We present an analysis of the variance in local, short-term (decadal) sea-level trends about the global-mean around the Atlantic, Pacific and Indian Ocean coastlines. These data are an indicative lower-bound of uncertainty in regional short-term trend deviations from global-mean projections.

For a recent decade of observations, from 2009-2018, the global-coastal mean sea level (here defined within $25 \mathrm{~km}$ of the coast and ignoring the Arctic and Antarctic coastlines) has been suppressed by climate variance, by $0.7 \mathrm{~mm} \mathrm{y}^{-1}$ in the coastal-mean. In particular, this increase is greatest in the Indian Ocean basin ( $2.0 \mathrm{~mm} \mathrm{y}^{-1}$ greater).

More than half of the decadal sea-level trend can be explained by a linear regression with major climate index trends at around $25 \%$ of global coastal (within $25 \mathrm{~km}$ of the coast) locations, rising to $54 \%$ of grid cells around the Pacific Ocean. The ENSO and PDO variability dominates here, and the open ocean variability observed by many previous studies extends to and around the coast most notably in the West Tropical Pacific and along the coast of the Americas. Our approach which has no lag or lead time introduced, finds lower variance explained in the low latitude East Pacific Ocean and in the mid-latitudes of the West Pacific. In the Indian Ocean, our method is most successful in the eastern basin, where the propagation of ENSOrelated sea-level disturbance dominates through the Indonesian Throughflow and therefore dominates the first EOF mode. In the Atlantic Ocean our approach works well in the Baltic, Black and Eastern Mediterranean Seas and along the west coast of North Africa (Eastern Tropical Atlantic Ocean). Notably this region of North Africa, and other regions where the variance explained is lower but still statistically significant such as the Caribbean Seas and Bay of Bengal, have a lack of good quality and long duration tide gauge data by which to evaluate decadal-scale variability needed to make helpful forecasts of sea-level trends over the mid-term.

The variability of GRD in total sea-level trend should not be ignored over timescales of the order of 10 years (Fig. 2). The variability in decadal-scale coastal sea-level trend over much of the coastal ocean is dominated by manometric and GRD sea-level components rather than steric sea level. The coasts where steric sea-level trend variability dominates the signal are mostly tropical or low latitude towards the west of ocean basins and at the oceanic extent of the continental shelf. Sea-level disturbances that originate as steric in the open ocean propagate onto the continental shelf as a mass signal at the local scale. Thus, sea-level trends in the open ocean that can be associated with steric forcing need to be propagated accordingly onto the shelf, i.e. using high-resolution models, to adequately forecast variability at the coast. Future anthropogenic or climate change influences on hydrology and ice mass change driven GRD will disproportionately affect some regions that historically display 
https://doi.org/10.5194/os-2022-3

Preprint. Discussion started: 7 February 2022

(c) Author(s) 2022. CC BY 4.0 License.

(c) (1)

low decadal variance, such as the Amazon Basin, the west coast of Africa from Niger, Congo and Zambezi hydrology, and the

Persian Gulf.

\section{Appendix A: CMIP6 models}

The CMIP6 models used in this study are given in Table A1.

Data availability. The CMIP6 model run and NEMO model run outputs are available to download from their original sources (ESGF (2021); www.jasmin.ac.uk). Additionally, CMIP6 model runs are available from the WCRP data portal at https://esgf-index1.ceda.ac.uk/ 350 search/cmip6-ceda/. Public archives of the NEMO ORCA0083-N006 model run are found at http://gws-access.ceda.ac.uk/public/nemo/runs/ ORCA0083-N06/means/ (Coward, 2016). The NEMO ocean model code and its documentation are available from https://www.nemo-ocean. eu. We use SSH data from satellite altimetry from the ESA SLCCI v2 project (ESA, 2018); GRD effect data provided by Frederikse (Frederikse et al., 2020a); and climate mode indices as cited in the text.

The data produced in this analysis and used to create the Figures and Tables is available to download from Zenodo with DOI:10.5281/zenodo.5849268 at https://zenodo.org/record/5849268\#.YeFtDGjP2Uk.

Author contributions. All authors contributed in devising the study. RB processed NEMO and CMIP6 model data and SR undertook the remaining data processing, data analysis, and lead manuscript writing. All authors contributed to interpretation of the results and reviewing the manuscript.

Competing interests. The authors declare no competing interests.

Acknowledgements. The authors were all supported by European Research Council (ERC) under the European Union's Horizon 2020 research and innovation programme under grant agreement No 694188, the GlobalMass project (globalmass.eu). JLB was additionally supported through a Leverhulme Trust Fellowship (RF-2016-718) and a Royal Society Wolfson Research Merit Award. We would like to thank Richard Westaway for project management and proof reading of this article.

The authors are very grateful for the assistance of Richard Westaway (University of Bristol) in editorial of the final manuscript for language and publication quality review.

The authors are grateful for the open availability of observational and derived data sets, as referenced in the text and data availability section. 
https://doi.org/10.5194/os-2022-3

Preprint. Discussion started: 7 February 2022

(C) Author(s) 2022. CC BY 4.0 License.

\begin{tabular}{|c|c|c|}
\hline Model Name & Model Centre & Resolution \\
\hline ACCESS-CM2 & CSIRO-ARCCSS & - \\
\hline ACCESS-ESM1-5 & CSIRO & - \\
\hline BCC-CSM2 & $\mathrm{BCC}$ & MR \\
\hline CAMS-CSM1-0 & CAMS & - \\
\hline CanESM5 & $\mathrm{CCCma}$ & - \\
\hline CAS-ESM2-0 & CAS & - \\
\hline CESM2 & NCAR & - \\
\hline CESM2-FV2 & NCAR & - \\
\hline CESM2-WACCM & NCAR & - \\
\hline CESM2-WACCM-FV2 & NCAR & - \\
\hline CIESM & THU & - \\
\hline CMCC-CM2 & $\mathrm{CMCC}$ & HR4 \\
\hline CMCC-CM2 & $\mathrm{CMCC}$ & SR5 \\
\hline E3SM-1-0 & USDOE & - \\
\hline E3SM-1-1 & USDOE & - \\
\hline E3SM-1-1-ECA & USDOE & - \\
\hline EC-Earth3 & EC-Earth-Consortium & - \\
\hline EC-Earth3-AerChem & EC-Earth-Consortium & - \\
\hline EC-Earth3-Veg & EC-Earth-Consortium & - \\
\hline EC-Earth3-Veg & EC-Earth-Consortium & LR \\
\hline FGOALS-f3-L & CAS & - \\
\hline FGOALS-g3 & CAS & - \\
\hline FIO-ESM-2-0 & FIO & - \\
\hline GFDL-CM4 & GFDL & - \\
\hline GFDL-ESM4 & GFDL & - \\
\hline GISS-E2-1-G & NASA-GISS & - \\
\hline GISS-E2-1-G-CC & NASA-GISS & - \\
\hline GISS-E2-1-H & NASA-GISS & - \\
\hline INM-CM4-8 & INM & - \\
\hline INM-CM5-0 & INM & - \\
\hline IPSL-CM6A & IPSL & LR \\
\hline KIOST-ESM & KIOST & - \\
\hline MIROC6 & MIROC & - \\
\hline MPI-ESM-1-2-HAM & HAMMOZ-Consortium & - \\
\hline MPI-ESM1-2 & MPI-M & LR \\
\hline MPI-ESM1-2 & MPI-M DWD DKRZ & HR \\
\hline MRI-ESM2-0 & MRI & - \\
\hline NESM3 & NUIST & - \\
\hline NorCPM1 & NCC & - \\
\hline NorESM2 & $\mathrm{NCC}$ & LM \\
\hline NorESM2 & $\mathrm{NCC}$ & MM \\
\hline SAM0-UNICON & SNU & - \\
\hline TaiESM1 & AST & - \\
\hline
\end{tabular}

Table A1. List of CMIP6 models used in this study. 
https://doi.org/10.5194/os-2022-3

Preprint. Discussion started: 7 February 2022

(c) Author(s) 2022. CC BY 4.0 License.

\section{References}

Becker, M., Karpytchev, M., Marcos, M., Jevrejeva, S., and Lennartz-Sassinek, S.: Do climate models reproduce complexity of observed sea level changes?, Geophysical Research Letters, 43, 5176-5184, https://doi.org/10.1002/2016GL068971, http://dx.doi.org/10.1002/ 2016GL068971, 2016GL068971, 2016.

Bingham, R. J. and Hughes, C. W.: Local diagnostics to estimate density-induced sea level variations over topography and along coastlines, Journal of Geophysical Research: Oceans, 117, https://doi.org/10.1029/2011JC007276, 2012.

Bos, M. S., Fernandes, R. M. S., Williams, S. D. P., and Bastos, L.: Fast error analysis of continuous GNSS observations with missing data, Journal of Geodesy, 87, 351-360, https://doi.org/10.1007/s00190-012-0605-0, http://dx.doi.org/10.1007/s00190-012-0605-0, 2013.

Carson, M., Köhl, A., and Stammer, D.: The Impact of Regional Multidecadal and Century-Scale Internal Climate Variability on Sea Level Trends in CMIP5 Models, Journal of Climate, 28, 853 - 861, https://doi.org/10.1175/JCLI-D-14-00359.1, 2015.

Carson, M., Lyu, K., Richter, K., Becker, M., Domingues, C. M., Han, W., and Zanna, L.: Climate Model Uncertainty and Trend Detection in Regional Sea Level Projections: A Review, Surveys in Geophysics, 40, 1631-1653, https://doi.org/10.1007/s10712-019-09559-3, 2019.

Coward, A. C.: Archive data from run 6 of the NEMO 1/12 ${ }^{\circ}$ global ocean model, Retrieved from https://gws-access.ceda.ac.uk/public/ nemo/runs/ORCA0083-N06/means/, 2016.

Dangendorf, S., Rybski, D., Mudersbach, C., Müller, A., Kaufmann, E., Zorita, E., and Jensen, J.: Evidence for long-term memory in sea level, Geophysical Research Letters, 41, 5530-5537, https://doi.org/10.1002/2014GL060538, http://dx.doi.org/10.1002/2014GL060538, 2014GL060538, 2014.

Dangendorf, S., Frederikse, T., Chafik, L., Klinck, J. M., Ezer, T., and Hamlington, B. D.: Data-driven reconstruction reveals large-scale ocean circulation control on coastal sea level, Nat. Clim. Chang., 11, 514-520, https://doi.org/10.1038/s41558-021-01046-1, 2021.

Dussin, R., Barnier, B., and Brodeau, L.: The making of Drakkar forcing set DFS5, Tech. rep., LGGE, 2016.

Emery, W. J. and Thomson, R. E.: Data Analysis Methods in Physical Oceanography, Elsevier Science, 2001.

ESA: Time series of gridded Sea Level Anomalies, Retrieved 10 April 2018 via http://www.esa-sealevel-cci.org/products, https://doi.org/10.5270/esa-sea_level_cci-MSLA-1993_2015-v_2.0-201612, 2018.

ESGF: WCRP Coupled Model Intercomparison Project (Phase 6) data portal, Retrieved from https://esgf-index1.ceda.ac.uk/search/ cmip6-ceda/ February 2021, 2021.

Eyring, V., Bony, S., Meehl, G. A., Senior, C. A., Stevens, B., Stouffer, R. J., and Taylor, K. E.: Overview of the Coupled Model Intercomparison Project Phase 6 (CMIP6) experimental design and organization, Geosci. Model Dev., 9, 1937-1958, https://doi.org/10.5194/gmd9-1937-2016, 2016.

Fasullo, J. T. and Nerem, R. S.: Altimeter-era emergence of the patterns of forced sea-level rise in climate models and implications for the future, Proceedings of the National Academy of Sciences, 115, 12 944-12949, https://doi.org/10.1073/pnas.1813233115, https://www. pnas.org/content/115/51/12944, 2018.

Fasullo, J. T., Gent, P. R., and Nerem, R. S.: Forced Patterns of Sea Level Rise in the Community Earth System Model Large Ensemble From 1920 to 2100, Journal of Geophysical Research: Oceans, 125, e2019JC016 030, https://doi.org/https://doi.org/10.1029/2019JC016030, 2020.

Frankcombe, L. M., McGregor, S., and England, M. H.: Robustness of the modes of Indo-Pacific sea level variability, Climate Dynamics, 45, 1281-1298, https://doi.org/10.1007/s00382-014-2377-0, http://dx.doi.org/10.1007/s00382-014-2377-0, 2015. 
https://doi.org/10.5194/os-2022-3

Preprint. Discussion started: 7 February 2022

Frederikse, T., Jevrejeva, S., Riva, R. E. M., and Dangendorf, S.: A Consistent Sea-Level Reconstruction and Its Budget on Basin and Global Scales over 1958-2014, Journal of Climate, 31, 1267-1280, https://doi.org/10.1175/JCLI-D-17-0502.1, 2018.

Frederikse, T., Landerer, F., Caron, L., Adhikari, S., Parkes, D., Humphrey, V. W., Dangendorf, S., Hogarth, P., Zanna, L., Cheng, L., and Wu, Y.-H.: The causes of sea-level rise since 1900, Total barystatic total.nc retrieved 21 August 2020 , https://doi.org/https://zenodo.org/record/3862995\#.YKTjNqhKiUk, 2020a.

Frederikse, T., Landerer, F., Caron, L., Adhikari, S., Parkes, D., Humphrye, V. W., Dangendorf, S., Hogarth, P., Zanna, L., Cheng, L., and

Wu, Y.-H.: The causes of sea-level rise since 1900, Nature, 54, 393-397, https://doi.org/10.1038/s41586-020-2591-3, https://www.nature. com/articles/s41586-020-2591-3, 2020b.

GCOS: GCOS Dipole Mode Index (DMI), Retrieved from https://psl.noaa.gov/gcos_wgsp/Timeseries/DMI/ November 2020, 2020.

Greatbatch, R. J.: A note on the representation of steric sea level in models that conserve volume rather than mass, J. Geophys. Res., 99 , 12 767-12 771, 1994.

Gregory, J. M., Griffies, S. M., Hughes, C. W., Lowe, J. A., Church, J. A., Fukumori, I., Gomez, N., Kopp, R. E., Landerer, F., Cozannet, G. L., Ponte, R. M., Stammer, D., Tamisiea, M. E., and van de Wal, R. S. W.: Concepts and Terminology for Sea Level: Mean, Variability and Change, Both Local and Global, Surveys in Geophysics, https://doi.org/10.1007/s10712-019-09525-z, 2019.

Griffies, S. M. and Greatbatch, R. J.: Physical processes that impact the evolution of global mean sea level in ocean climate models, Ocean Modelling, 51, 37-72, https://doi.org/https://doi.org/10.1016/j.ocemod.2012.04.003, 2012.

Haigh, I. D., Wahl, T., Rohling, E. J., Price, R. M., Pattiaratchi, C. B., Calafat, F. M., and Dangendorf, S.: Timescales for detecting a significant acceleration in sea level rise, Nature Comms., 5, 3635, https://doi.org/10.1038/ncomms4635, 2014.

Hamlington, B., Frederikse, T., Thompson, P., Willis, J., Nerem, R., and Fasullo, J.: Past, Present and Future Pacific Sea Level-Change, Earth's Future, n/a, 2020EF001 839, https://doi.org/https://doi.org/10.1029/2020EF001839, https://agupubs.onlinelibrary.wiley.com/doi/ abs/10.1029/2020EF001839, 2020a.

Hamlington, B. D., Leben, R. R., Strassburg, M. W., Nerem, R. S., and Kim, K.-Y.: Contribution of the Pacific Decadal Oscillation to global mean sea level trends, Geophysical Research Letters, 40, 5171-5175, https://doi.org/10.1002/grl.50950, http://dx.doi.org/10.1002/ grl.50950, 2013.

Hamlington, B. D., Strassburg, M. W., Leben, R. R., Han, W., Nerem, R. S., and K-Y., K.: Uncovering the anthropogenic sea-level rise signal in the Pacific Ocean, Nature Climate Change, 4, 782-785, https://doi.org/10.1038/nclimate2307, http://dx.doi.org/10.1038/nclimate2307, 2014.

Hamlington, B. D., Fasullo, J. T., Nerem, R. S., Kim, K.-Y., and Landerer, F. W.: Uncovering the Pattern of Forced Sea Level Rise in the Satellite Altimeter Record, Geophysical Research Letters, 46, 4844-4853, https://doi.org/https://doi.org/10.1029/2018GL081386, 2019.

Hamlington, B. D., Frederikse, T., Nerem, R. S., Fasullo, J. T., and Adhikari, S.: Investigating the Acceleration of Regional Sea Level Rise During the Satellite Altimeter Era, Geophysical Research Letters, 47, e2019GL086528, https://doi.org/https://doi.org/10.1029/2019GL086528, 2020b.

Hamlington, B. D., Piecuch, C. G., Reager, J. T., Chandanpurkar, H., Frederikse, T., Nerem, R. S., Fasullo, J. T., and Cheon, S.-H.: Origin of interannual variability in global mean sea level, Proceedings of the National Academy of Sciences, 117, 13983-13990, https://doi.org/10.1073/pnas.1922190117, 2020c.

Holgate, S. J., Matthews, A., Woodworth, P. L., Rickards, L. J., Tamisiea, M. E., Bradshaw, E., Foden, P. R., Gordon, K. M., Jevrejeva, S., and Pugh, J.: New Data Systems and Products at the Permanent Service for Mean Sea Level, Journal of Coastal Research, 29, 493-504, https://doi.org/10.2112/JCOASTRES-D-12-00175.1, http://dx.doi.org/10.2112/JCOASTRES-D-12-00175.1, 2013. 
https://doi.org/10.5194/os-2022-3

Preprint. Discussion started: 7 February 2022

(c) Author(s) 2022. CC BY 4.0 License.

(c) (i)

IPCC: IPCC Special Report on the Ocean and Cryosphere in a Changing Climate, Tech. rep., Intergovernmental Panel on Climate Change (IPCC), 2019.

Kleinherenbrink, M., Riva, R., and Sun, Y.: Sub-basin-scale sea level budgets from satellite altimetry, Argo floats and satellite gravimetry: a case study in the North Atlantic Ocean, Ocean Science, 12, 1179-1203, https://doi.org/10.5194/os-12-1179-2016, https://www.ocean-sci. net/12/1179/2016/, 2016.

Landerer, F. W., Jungclaus, J. H., and Marotzke, J.: Regional Dynamic and Steric Sea Level Change in Response to the IPCC-A1B Scenario, Journal of Physical Oceanography, 37, 296 - 312, https://doi.org/10.1175/JPO3013.1, https://journals.ametsoc.org/view/journals/phoc/37/ 2/jpo3013.1.xml, 2007.

Legeais, J.-F., Ablain, M., Zawadzki, L., Zuo, H., Johannessen, J. A., Scharffenberg, M. G., Fenoglio-Marc, L., Fernandes, M. J., Andersen, O. B., Rudenko, S., Cipollini, P., Quartly, G. D., Passaro, M., Cazenave, A., and Benveniste, J.: An improved and homogeneous altimeter sea level record from the ESA Climate Change Initiative, Earth System Science Data, 10, 281-301, https://doi.org/10.5194/essd-10-2812018, https://www.earth-syst-sci-data.net/10/281/2018/, 2018.

Llovel, W., Penduff, T., Meyssignac, B., Molines, J.-M., Terray, L., Bessières, L., and Barnier, B.: Contributions of Atmospheric Forcing and Chaotic Ocean Variability to Regional Sea Level Trends Over 1993-2015, Geophysical Research Letters, 45, 13,405-13,413, https://doi.org/https://doi.org/10.1029/2018GL080838, https://agupubs.onlinelibrary.wiley.com/doi/abs/10.1029/2018GL080838, 2018.

Marshall, G. J.: An observation-based Southern Hemisphere Annular Mode Index, Retrieved from https://legacy.bas.ac.uk/met/gjma/sam. html August 2020, 2020.

Marzocchi, A.-M., Hirschi, J. J., Holliday, N. P., Cunningham, S. A., Blaker, A. T., and Coward, A. C.: The North Atlantic subpolar circulation in an eddy-resolving global ocean model, Journal of Marine Systems, https://doi.org/10.1016/j.jmarsys.2014.10.007, 2015.

Meyssignac, B., Slangen, A. B. A., Melet, A., Church, J. A., Fettweis, X., Marzeion, B., Agosta, C., Ligtenberg, S. R. M., Spada, G., Richter, K., Palmer, M. D., Roberts, C. D., and Champollion, N.: Evaluating Model Simulations of Twentieth-Century Sea-Level Rise. Part II: Regional Sea-Level Changes, Journal of Climate, 30, 8565 - 8593, https://doi.org/10.1175/JCLI-D-17-0112.1, 2017.

Moat, B. I., Josey, S. A., Sinha, B., Blaker, A. T., Smeed, D. A., McCarthy, G. D., and et al.: Major variations in subtropical North Atlantic heat transport at short (5 day) timescales and their causes, Journal of Geophysical Research: Oceans, 121, 3237-3249, https://doi.org/10.1002/2016JC011660, 2016.

Nerem, R. S., Beckley, B. D., Fasullo, J. T., Hamlington, B. D., Masters, D., and Mitchum, G. T.: Climate-change-driven accelerated sea-level rise detected in the altimeter era, Proceedings of the National Academy of Sciences, 115, 2022-2025, https://doi.org/10.1073/pnas.1717312115, https://www.pnas.org/content/115/9/2022, 2018.

Nidheesh, A., Lengaigne, M., and Vialard, J.: Natural decadal sea-level variability in the Indian Ocean: lessons from CMIP models, CLimate Dynamics, 53, 5653-5673, https://doi.org/10.1007/s00382-019-04885-z, 2019.

NOAA-CPC: NOAA-CPC Arctic Oscillation Index (AO), Retrieved from https://www.cpc.ncep.noaa.gov/products/precip/CWlink/daily_ ao_index/ao_index.html November 2020, 2020.

NOAA-NCEI: NOAA-ESRL PSL Multivariate ENSO Index (MEI), Retrieved from https://www.psl.noaa.gov/enso/mei.old/ September 475 2020., 2020a.

NOAA-NCEI: NCEI North Atlantic Oscillation (NAO) index, Retrieved from https://www.ncdc.noaa.gov/teleconnections/nao/ August 2020., $2020 \mathrm{~b}$.

NOAA-NCEI: NCEI Pacific Decadal Oscillation (PDO)index, Retrieved from https://www.ncdc.noaa.gov/teleconnections/pdo/ February 2020., 2020c. 
https://doi.org/10.5194/os-2022-3

Preprint. Discussion started: 7 February 2022

(c) Author(s) 2022. CC BY 4.0 License.

(c) (i)

Peltier, W. R.: Stokes coefficients for the ICE-6G_C/D VM5a GIA forward model, Retrieved 23 July 2018 from www.atmosp.physics. utoronto.ca/ peltier/data.php, 2018.

Peltier, W. R., Argus, D. F., and Drummond, R.: Space geodesy constrains ice age terminal deglaciation: The global ICE-6G_C (VM5a) model, Journal of Geophysical Research: Solid Earth, 120, 450-487, https://doi.org/10.1002/2014JB011176, https://agupubs.onlinelibrary. wiley.com/doi/abs/10.1002/2014JB011176, 2015.

Penduff, T., Llovel, W., Close, S., Garcia-Gomez, I., and Leroux, S.: Processing Choices Affect Ocean Mass Estimates From GRACE, Journal of Geophysical Research: Oceans, 124, 1029-1044, https://doi.org/10.1029/2018JC014341, https://agupubs.onlinelibrary.wiley. com/doi/abs/10.1029/2018JC014341, 2019.

Peyser, C. E., Yin, J., Landerer, F. W., and Cole, J. E.: Pacific sea level rise patterns and global surface temperature variability, Geophysical Research Letters, 43, 8662-8669, https://doi.org/10.1002/2016GL069401, http://dx.doi.org/10.1002/2016GL069401, 2016GL069401, 2016.

Richter, K., Meyssignac, B., Slangen, A. B. A., Melet, A., Church, J. A., Fettweis, X., Marzeion, B., Agosta, C., Ligtenberg, S. R. M., Spada, G., Palmer, M. D., Roberts, C. D., and Champollion, N.: Detecting a forced signal in satellite-era sea-level change, Environmental Research Letters, 15, 094 079, https://doi.org/10.1088/1748-9326/ab986e, https://doi.org/10.1088/1748-9326/ab986e, 2020.

Sérazin, G., Penduff, T., Grégorio, S., Barnier, B., Molines, J.-M., and Terray, L.: Intrinsic Variability of Sea Level from Global Ocean Simulations: Spatiotemporal Scales, Journal of Climate, 28, 4279 - 4292, https://doi.org/10.1175/JCLI-D-14-00554.1, https://journals. ametsoc.org/view/journals/clim/28/10/jcli-d-14-00554.1.xml, 2015.

Sérazin, G., Meyssignac, B., Penduff, T., Terray, L., Barnier, B., and Molines, J.-M.: Quantifying uncertainties on regional sea level change induced by multidecadal intrinsic oceanic variability, Geophysical Research Letters, 43, 8151-8159, https://doi.org/10.1002/2016GL069273, http://dx.doi.org/10.1002/2016GL069273, 2016GL069273, 2016.

TEOS-10: Release on the IAPWS Formulation 2008 for the Thermodynamic Properties of Seawater, Tech. rep., IAPWS, www.teos-10.org, 2008.

The NEMO Working Group: The NEMO Ocean Engine, Tech. rep., Institut Pierre-Simon Laplace (IPSL), https://doi.org/https://doi.org/10.5281/zenodo.1464816, 2019.

Wang, J., Church, J. A., and Zhang, X.: Reconciling global mean and regional sea level change in projections and observations, Nat. Comms., 12, 990, https://doi.org/10.1038/s41467-021-21265-6, 2021.

Woodworth, P. L., Melet, A., Marcos, M., Ray, R. D., Wöppelmann, G., Sasaki, Y. N., Cirano, M., Hibbert, A., Huthnance, J. M., Monserrat, S., and Merrifield, M. A.: Forcing Factors Affecting Sea Level Changes at the Coast, Surveys in Geophysics, 40, 1351-1397, https://doi.org/10.1007/s10712-019-09531-1, https://link.springer.com/article/10.1007/s10712-019-09531-1, 2019.

Yin, J., Griffies, S. M., and Stouffer, R. J.: Spatial Variability of Sea Level Rise in Twenty-First Century Projections, Journal of Climate, 23, 4585 - 4607, https://doi.org/10.1175/2010JCLI3533.1, https://journals.ametsoc.org/view/journals/clim/23/17/2010jcli3533.1.xml, 2010.

Zhang, X. and Church, J. A.: Sea level trends, interannual and decadal variability in the Pacific Ocean, Geophysical Research Letters, 39, n/a-n/a, https://doi.org/10.1029/2012GL053240, http://dx.doi.org/10.1029/2012GL053240, 121701, 2012. 